\title{
Change over time of the mutagenicity in the lungs of $g p t$ delta transgenic mice by extract of airborne particles collected from ambient air in the Tokyo metropolitan area
}

Yasunobu Aoki ${ }^{1 *}$ D, Daisuke Nakajima ${ }^{1}$, Michiyo Matsumoto ${ }^{1}$, Mayuko Yagishita', Michi Matsumoto', Rie Yanagisawa', Sumio Goto², Kenichi Masumura ${ }^{3}$ and Takehiko Nohmi ${ }^{3}$

\begin{abstract}
Background: Previously we found that DNA adducts were accumulated in the lungs of the rats exposed to ambient air in the Tokyo metropolitan area. To examine chronological change in in vivo mutagenicity of airborne particles, extracts produced from samples of total suspended particulates (TSP) collected from urban air in 1980, 1990, and 2010 in the Tokyo metropolitan area were intratracheally administered into the lungs of gpt delta mice, and differences in mutation and mutant frequency were determined by using the gpt assay. In vivo mutations induced by the extracts were characterized and mutation hotspots were identified by DNA sequencing of the mutated gpt gene.

Results: Administration of the 1990 extract at a dose of $0.3 \mathrm{mg} / \mathrm{animal}$ significantly elevated total mutant frequency to 3.3-times that in vehicle control, and the in vivo mutagenicity of the extract (induced mutation frequency per milligram extract) was estimated to be 2.0- and 2.4-times higher than that of the 2010 and 1980 extract, respectively. G-to-A transition was the most common base substitution in the vehicle control mice. However, administration of the 1990 extract increased the frequency of G-to-T transversion, which is a landmark base substitution induced by oxidative stress; furthermore, when the extract was administered at a dose of $0.15 \mathrm{mg}$, the mutant and mutation frequencies of G-to-T transversion were significantly increased to frequencies comparable with those of G-to-A transition. Similar increases in the mutant and mutation frequencies of G-to-T transversion were observed after administration of the 2010 extract. Hotspots (mutation foci identified in three or more mice) of G-to-A transition mutations at nucleotides 64 and 110 were induced by the 1980, 1990, and 2010 extracts; a hotspot of G-to-T transversions at nucleotide 406 was also induced by the 2010 extract. Previously, we showed that diesel exhaust particles or their extract, as well as 1,6-dinitropyrene, administered to mice induced these hotspots of G-to-A transitions.
\end{abstract}

Conclusions: The results of the present study suggested that mutagenesis induced by extracts produced from TSP collected in the Tokyo metropolitan area induced in vivo mutagenicity via the same mechanism underlying the induction of in vivo mutagenicity by components of diesel exhaust.

Keywords: Air pollutant, Carinogen, Environmental mutagen, Risk assessment, Transgenic rodent assay, Urban air

\footnotetext{
* Correspondence: ybaoki@nies.go.jp

${ }^{1}$ National Institute for Environmental Studies, Center for Health and

Environmental Risk Research, 16-2 Onogawa, Tsukuba, Ibaraki 305-8506,

Japan

Full list of author information is available at the end of the article
}

(c) The Author(s). 2018 Open Access This article is distributed under the terms of the Creative Commons Attribution 4.0 International License (http://creativecommons.org/licenses/by/4.0/), which permits unrestricted use, distribution, and

reproduction in any medium, provided you give appropriate credit to the original author(s) and the source, provide a link to the Creative Commons license, and indicate if changes were made. The Creative Commons Public Domain Dedication waiver (http://creativecommons.org/publicdomain/zero/1.0/) applies to the data made available in this article, unless otherwise stated. 


\section{Introduction}

Air pollution is a prioritized public health issue that is yet to be resolved in urban areas in industrial countries [1]. The major air pollutants in ambient air are oxidized gases (e.g., nitrogen oxide and ozone) and airborne particles generated by automobile engines or the burning of fossil fuels (e.g., coal and petroleum), and these pollutants are associated with respiratory organ diseases such as asthma, cardiovascular disease, and lung cancer [2-6]. Air pollution has long been recognized as a localized issue, but recently it has become a global issue because transboundary air pollutants are suspected to cause diseases in humans [7-9]. Airborne particles contain various mutagens such as polycyclic aromatic hydrocarbons (PAHs), nitrated PAHs, and oxidized aromatic compounds (e.g., quinones). Some mutagenic PAHs (e.g., benzo[a]pyrene $(\mathrm{BaP})$ and dibenz $[a, h]$ anthracene $(\mathrm{dBahA}))$ and their related compounds are suspected causes of lung cancer [10-12]. Although outdoor air pollution is recognized as a human carcinogen (Group I substance classified by the World Health Organization/International Agency for Research on Cancer) [13], the mechanisms for in vivo mutagenicity and carcinogenicity of airborne particles in urban air, and therefore the health risk posed by mixture of air pollutants, remain to be determined.

The mutagenicity of airborne particles collected in various countries has been examined by using in vitro bioassay systems such as the Ames test $[14,15]$. In Japan, studies have shown that mutagenic airborne particles are ubiquitously present in air samples collected in large cities $[16,17]$. This suggests that inhaled airborne particles may have genotoxic effects in the lungs and other respiratory organs of humans. Indeed, inhalation of tobacco smoke or coke-oven emissions has been shown to induce DNA adduct formation, micronucleus formation, and DNA strand breaks in surrogate tissues (e.g., white blood cells) in rodents $[8,18,19]$. However, few studies have examined whether polluted urban air has genotoxic effects in the lungs and respiratory organs in humans.

In 1996-1997, our research group performed an in situ study in which we exposed rats to ambient air from the Tokyo metropolitan area, and we found that DNA adducts, which may be products with PAH, were accumulated in the lungs, nasal mucosa, and livers of the rats after 4 weeks of exposure [20]. This suggests that urban air containing particulate matters has the potential to produce DNA adducts in the lungs and respiratory organs in humans, and we hypothesized that in vivo mutagenesis would be elevated in those organs.

The gpt delta transgenic rodent is a useful tool for evaluating the mutagenicity of environmental mutagens (for a review, see [21-24]). In the gpt delta system, the Escherichia coli gpt gene encoding guanine phosphoribosyltransferase is carried on a lambda phage shuttle vector that is integrated into the rodent genomic DNA. After gpt delta rodents are exposed to a mutagen, the shuttle vector is rescued from the genomic DNA as phage particles, which are then infected to host $E$. coli in and the mutated gpt gene is detected by the appearance of 6-thioguanineresistant colonies. The gpt delta system can be used to detect large deletions of genomic DNA. Previously, we used the gpt delta mouse system to show that inhalation of diesel exhaust increased in vivo mutagenesis in the mouse lung [25] and testis [26], and that intratracheal administration of diesel exhaust particles or dieselexhaust-particle extract increased mutation frequency in the lung [25].

In the present study, we examined the chronological change in in vivo mutagenesis induced by airborne particles collected in 1980-2010 for retrospective study for assessing hazard of air pollution in past 40 years, as a preliminary study to an in situ exposure study using urban air. Extracts made from TSP collected from the Tokyo metropolitan area in 1980, 1990, and 2010 were administered to the lungs of gpt delta mice via a single intratracheal instillation, and the in vivo mutagenicity of the extracts was determined by means of the gpt assay. We estimated the mutant and mutation frequencies of the induced point mutations, and found that the 1990 extract had the highest mutagenicity of the three extracts. We also determined the mutation spectrum for each of the extracts and identified mutation hotspots on the gpt gene. Our results presented in this report, together with the results of previous studies, suggest that oxidative stress is the underlying mechanism through which the airborne particles induced mutagenesis.

\section{Materials and methods}

\section{Collection of TSP from urban air}

TSP was collected by using a high-volume air sampler, as described previously [27]. Briefly, TSP was collected by using a quartz fiber filter (Pallflex 2500 QAT-UP, $8 \times$ 10 in.; Pall Corporation Port Washington NY, USA) over a 23-h period extending from 10 am to 9 am the next day. The flow rate was set at $700 \mathrm{~L} / \mathrm{min}$ and approximately $1000 \mathrm{~m}^{3}$ of air was sampled over the 23-h period every 6 days (about 60 times sampling through a year). Sampling was undertaken at Shirokanedai, Minato Ward, Tokyo, Japan (sampling point: former building of the National Institute of Public Health; $35.6388 \mathrm{~N}, 139.7264 \mathrm{E})$ in 1980 and 1990, and at Kagurazaka, Shinjuku Ward, Tokyo, Japan (sampling point: Tokyo University of Science; 35.6994 N, 139.7414E) in 2010. The distance between the two sampling points is approximately $6 \mathrm{~km}$. The amount of TSP collected was calculated by subtracting the weight of the filter before sampling from that after sampling. After sampling, the quartz fiber filter was folded in two with the sample retained on the inside of the fold, and the 
filter was then wrapped in aluminum foil and stored at $-80{ }^{\circ} \mathrm{C}$.

\section{Extract preparation and determination of PAH concentrations}

The particle-carrying portion of the quartz filter was cut equally based on the total filter area. Cutting area varies from year to year, and the area was calculated so that TSP becomes about $500 \mathrm{mg}$ when all the cut samples in the year are put together. The annual cut filter samples were combined and Soxhlet extracted for $24 \mathrm{~h}$ with $250 \mathrm{~mL}$ of dichloromethane. The extract was concentrated by using a rotary evaporator (R-205, B-490, Büchi Labortechnik AG, Switzerland) set at a pressure of $39,900 \mathrm{~Pa}$ [27], and then dried to a solid in a vial under gentle nitrogen flow.

To prepare samples for gas chromatography-mass spectrometry, $200 \mu \mathrm{g}$ of extract was re-dissolved in $30 \mathrm{~mL}$ of hexane, and then $20 \mathrm{ng}$ of deuterated PAHs (ES-2528, Cambridge Isotope Laboratories, Inc., Tewksbury, MA, USA) was added as an internal standard. The re-dissolved extract was again concentrated by using a rotary evaporator set at a pressure of $23,940 \mathrm{~Pa}$ [28]. A small amount of the concentrated hexane solution was then added to a preconditioned silica gel cartridge (Sep-Pak Silica Plus, Waters Corp. Milford, MA, USA) and eluted with $6 \mathrm{~mL}$ of dichloromethane-hexane $(8: 2 \mathrm{v} / \mathrm{v})$. An aliquot $(100 \mu \mathrm{L})$ of $\mathrm{n}$-nonane was added to the eluent and the resulting solution was concentrated to $100 \mu \mathrm{L}$ under gentle nitrogen flow. Finally, the solution was transferred to an insert vial (C-4000-2 W, $2 \mathrm{~mL}$, National Scientific Supply Co., Claremont, CA, USA) and the amounts of PAHs in the extract were determined by means of gas chromatography-mass spectrometry, as previously reported [27].

\section{Intratracheal administration}

gpt delta mice carrying approximately 80 copies of lambda EG10 on each chromosome 17 in a C57BL/6 J background [21] and C57BL/6 J mice were purchased from Japan SLC (Shizuoka, Japan). Twenty milligrams of dried extract in a glass vial was wetted with $17 \mu \mathrm{L}$ of dimethyl sulfoxide (DMSO; Sigma, St. Louis), and $3.3 \mathrm{~mL}$ of PBS (pH 7.4; Gibco BRL, Life Technology, Grand Island, NY) containing $0.05 \%(v / v)$ Tween 80 (Nacalai Tesque, Kyoto, Japan) was added to the vial. Immediately before administration, the extract was solubilized by sonication and diluted to the required concentration with the vehicle (PBS containing $0.05 \%(\mathrm{v} / \mathrm{v})$ Tween 80 and $0.5 \%(\mathrm{v} / \mathrm{v}) \mathrm{DMSO})$. For analyzing in vivo mutation, the extract $(0.15-0.9 \mathrm{mg}$, the amount was indicated in the text) in $100 \mu \mathrm{L}$ of the vehicle was administered to the lungs of male gpt delta mice (9-weeks old, 4-6 animals per a group) via a single intratracheal instillation [25]. For histopathological examination, 2010 extract $(0.15,0.3$ or $0.6 \mathrm{mg}$ ) in $100 \mu \mathrm{L}$ of the vehicle was administered to the lungs of male gpt delta mice (9-weeks old, 2 animals per a group).

1,2-Naphthoquinone (1,2-NQ) was dissolved in DMSO at a concentration of $40 \mathrm{mg} / \mathrm{mL}$, and diluted to 6 or $12 \mu \mathrm{g} / \mathrm{mL}$ in PBS containing $0.05 \%(v / \mathrm{v})$ Tween 80 and $0.1 \%(\mathrm{v} / \mathrm{v})$ DMSO immediately before administration. 1,2-NQ (300 or $600 \mathrm{ng}$ in $50 \mu \mathrm{L}$ ) was twice administered to the lungs of male gpt delta mice (9-weeks old) via intratracheal instillation with a 14-day interval between instillations; these dose of 1,2-NQ were referred from a previous report [29], in which total $948 \mathrm{ng}$ of $1,2-\mathrm{NQ}$ per animal (158 ng per animal every week for 6 weeks) animal was already shown to be the tolerable dose.

For the intratracheal instillation, mice were anesthetized with $4 \%$ halothane (Hoechst Japan, Tokyo, Japan) until unresponsive to a tactile stimulus. The mice were then placed on a restraining board with linen threads to hold the mouth open, and the extract was instilled into the trachea via a polyethylene tube [25]. Control mice were treated with $100 \mu \mathrm{L}$ PBS containing $0.05 \%$ Tween 80 and $0.5 \%$ DMSO in the extract experiment, or $50 \mu \mathrm{L}$ PBS containing $0.05 \%$ Tween 80 and $0.1 \%$ DMSO in the 1,2-NQ experiment.

Mice were euthanized 14 days after the single instillation of extract or the second instillation of 1,2-NQ. In this study, we took the same duration after the instillation as our previous study for examining in vivo mutagenesis of extract made from diesel exhaust particles [25]. For analyzing in vivo mutation, the lungs were removed, rinsed in PBS and then weighed. After frozen in liquid nitrogen, the lungs were stored at $-80{ }^{\circ} \mathrm{C}$. For histopathological examination, the lungs were fixed in situ by perfusing with $10 \%$ formalin neutral buffer solution (Nacalai, Kyoto, Japan) according to the procedure as previously reported [30], and were store in $10 \%$ formalin neutral buffer solution at $4{ }^{\circ} \mathrm{C}$.

\section{Histopathological examination of lungs}

Fixed mouse left lungs were embedded in paraffin. The middle region of left lung was sliced at $1 \mu \mathrm{m}$, and was stained with hematoxylin and eosin (HE). The histopathologic changes were observed in a light microscope (Keyence model BZ-X710, Osaka, Japan).

\section{gpt mutation assay}

The gpt assay was performed as described previously [31]. Briefly, DNA was extracted from lung tissue by using a RecoverEase DNA Isolation Kit (Agilent Technologies, Santa Clara, CA, USA) and lambda EG10 phages were rescued by using Transpack Packaging Extract (Agilent Technologies). E. coli YG6020 were infected with the rescued phages, inoculated to M9 salt plates containing 
chloramphenicol $(\mathrm{Cm})$ and 6-thioguanine (6-TG), and then incubated for $72-90 \mathrm{~h}$ at $37{ }^{\circ} \mathrm{C}$, which enabled selection of colonies harboring a plasmid carrying both the gene for chloramphenicol acetyltransferase as well as a mutated gpt gene. Isolates exhibiting the 6-TG-resistant phenotype were cultured overnight at $37{ }^{\circ} \mathrm{C}$ in Luria-Bertani (LB) broth containing $25 \mu \mathrm{g} / \mathrm{mL} \mathrm{Cm}$, harvested by centrifugation (7000 rpm, $10 \mathrm{~min}$ ), and then stored at $-80^{\circ} \mathrm{C}$.

\section{Polymerase chain reaction and DNA sequencing of the 6-TG-resistant mutants}

A 739-bp DNA fragment containing gpt was amplified by means of polymerase chain reaction and sequenced as described previously with slight modification [31, 32].

\section{gpt-mutant frequency}

gpt-Mutant frequency was calculated by dividing the number of colonies growing on agar plates containing $\mathrm{Cm}$ and 6-TG by the number of colonies growing on agar plates containing $\mathrm{Cm}$ alone. Mutation frequency was defined as the frequency at which independent mutants arose in the same animal. The frequencies for each type of mutation were calculated by dividing the number of each type of mutation in each group by the total number of mutations.

The in vivo mutagenic potency in the lung was defined as induced mutation frequency ['average mutation frequency at a dose of extract administered' minus 'average mutation frequency of the corresponding vehicle control'] per amount of extract (mg) administered into the lung.

\section{Statistical analysis}

All data are expressed as mean \pm SD. Differences were examined by using Student's $t$-test; $P<0.05$ was considered statistically significant.

\section{Results}

\section{Analysis of TSP extract}

To determine the in vivo mutagenicity of components of TSP in urban air, TSP was collected in Tokyo metropolitan area at Shirokanedai, Minato Ward in 1980 and 1990, and at Kagurazaka, Shinjuku Ward, Tokyo, Japan in 2010. The TSP collected in1980 and 2010 were selected as oldest and newest one, respectively, among our samples, and the TSP collected in 1990 was selected for examining the chronological change in in vivo mutagenicity at the same sampling point, Shirokanedai. From the air samplings in 1980, 1990, and 2010, 454.34, 447.00, and $484.63 \mathrm{mg}$ of TSP, respectively, was subjected to dichloromethane extraction, which provided $62.87,58.41$, and $65.50 \mathrm{mg}$ of dried extract, respectively $(0.138,0.131$, and $0.135 \mathrm{mg}$ extract/mg TSP, respectively). The concentrations of all of the PAHs in the extracts we examined
Table 1 Concentrations of polycyclic aromatic hydrocarbons contained in the three extracts

\begin{tabular}{lllllllllll}
\hline \multirow{2}{*}{$\begin{array}{l}\text { Sampling } \\
\text { time }\end{array}$} & \multicolumn{10}{l}{ Concentration (ng/mg extract) } \\
\cline { 2 - 10 } & FLN & Pyr & BaA & Chy & BbF & BkF & BaP & dBahA & IndP & BghiP \\
\hline 1980 & 31.7 & 32.0 & 31.7 & 55.5 & 55.4 & 19.5 & 31.8 & 2.6 & 56.5 & 66.3 \\
1990 & 20.1 & 17.9 & 16.7 & 31.1 & 32.3 & 9.6 & 15.4 & 2.0 & 26.8 & 27.0 \\
2010 & 18.3 & 13.4 & 7.5 & 17.4 & 18.4 & 5.2 & 8.3 & 1.6 & 12.2 & 12.8 \\
\hline FLN fluorene, Pyr pyrene, BaA benz[a]anthracene, Chy chrysene, BbF \\
$\begin{array}{l}\text { benzo[b]fluorene, BkF benzo[kfluorene, BaP benzo[a]pyrene, dBahA } \\
\text { dibenz[ah]anthracene, IndP indeno[1,2,3-cd] pyrene, BghiP benzo[ghi]perylene }\end{array}$
\end{tabular}

were decreased from 1980 to 2010 (Table 1). Especially, concentrations of the potent mutagenic and carcinogenic PAHs, BaP and dBahA [10-12], were decreased from 1980 to 2010 (BaP: 1980, $31.8 \mathrm{ng} / \mathrm{mg}$ extract; 2010, $8.3 \mathrm{ng} / \mathrm{mg}$ extract; dBahA: 1980, $2.6 \mathrm{ng} / \mathrm{mg}$ extract; 2010, $1.6 \mathrm{ng} / \mathrm{mg}$ extract).

\section{In vivo mutagenicity of the TSP extracts}

To examine genomic mutations induced by the extracts, maximum $0.6 \mathrm{mg}$ of 1990 or 2010 extract were intratracheally instilled to gpt delta mice. This dose was assumed to be adequate for detecting in vivo mutation induced by the extracts, because we previously observed significant increase in mutant frequency in the lung by intratracheal administration of $0.5 \mathrm{mg}$ of diesel exhaust particles or $0.2 \mathrm{mg}$ of extract made from diesel exhaust particles [25]. Maximum dose of 1980 extract was set to be $0.9 \mathrm{mg}$, since the mutagenicity of 1980 extract was expected to be lower than those of other extracts by our preliminary experiment. The mutations were identified by the gpt assay, and the mutant and mutation frequencies induced in the lungs of the mice by the 1980, 1990, and 2010 extracts were compared (Fig. 1 and Additional file 1: Table S1).

Administration of the 1990 extract at a dose of 0.15 and $0.3 \mathrm{mg}$ (approximately $6 \mathrm{mg} / \mathrm{kg}$ body weight and $12 \mathrm{mg} / \mathrm{kg}$ body weight, respectively) significantly increased total mutant frequency to 2.0 - and 3.3 times that observed in the mice administered vehicle control $\left(0.69 \times 10^{-5}\right.$ and $1.16 \times 10^{-5}$, respectively, vs. $0.35 \times 10^{-5}$; Fig. $1 \mathrm{~b}$ ). Lower total mutant frequencies were observed at higher doses in mice administered the 1980 and 1990 extracts, and this may be due to the toxicity in the lung induced by the extracts, as has been demonstrated with intratracheal administration of 1,6-dinitropyrene, which is a potent mutagen contained in diesel exhaust particles [33]. Actually, a significant decrease in the body weight by administration of 1990 extract at a dose of $0.6 \mathrm{mg}$ (Additional file 2: Figure S1E) suggests that systemic toxicity was induced by this extract at the highest dose $(0.6 \mathrm{mg})$. Because we estimated the average concentration of extract in the air sampled in 1990 as $0.0105 \mathrm{mg} / \mathrm{m}^{3}, 0.3 \mathrm{mg}$ of 1990 extract would be contained in $28.6 \mathrm{~m}^{3}$ of air, which is approximately the lifetime inhalation volume of a male 


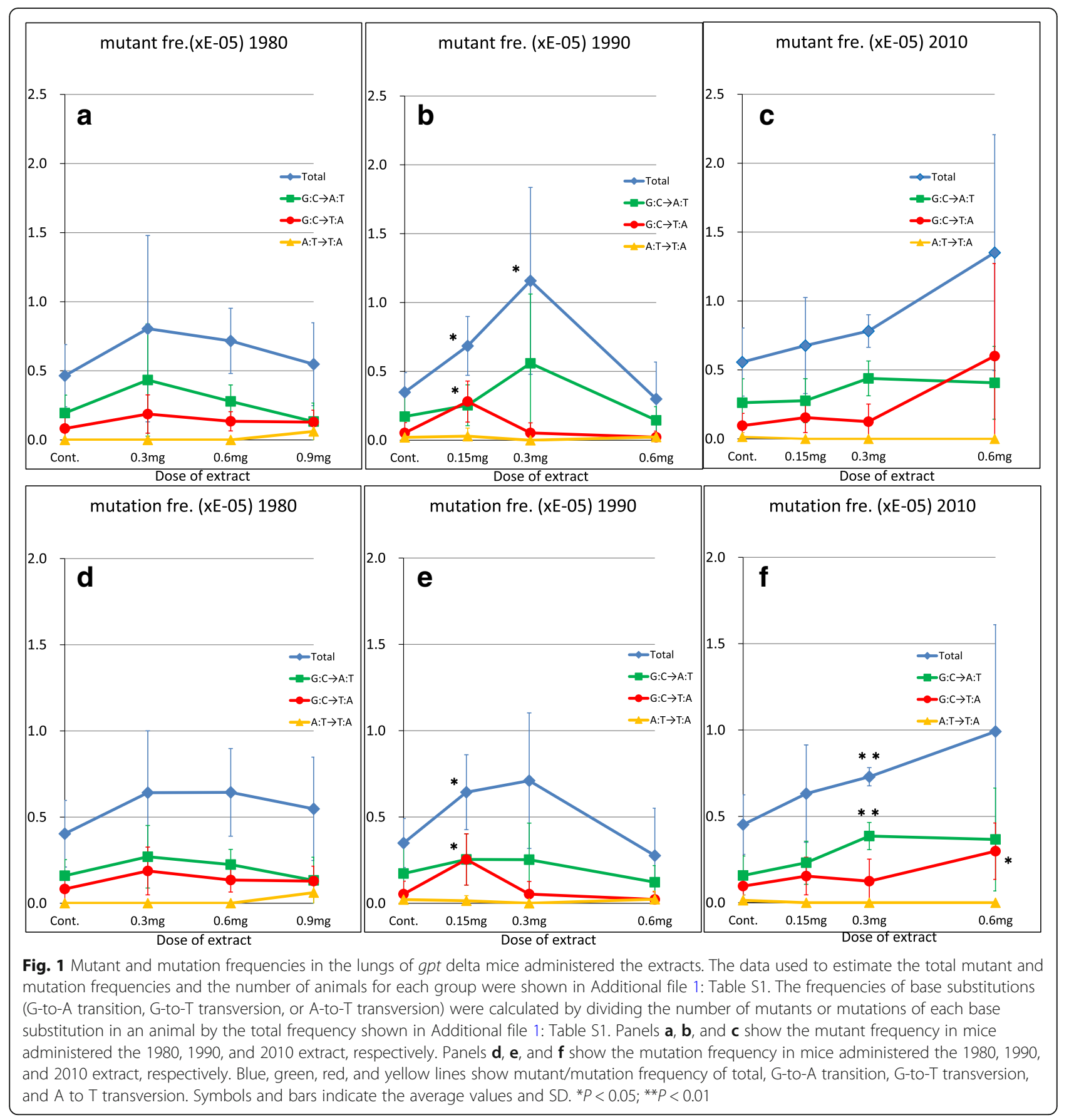

mouse (assuming an average lifespan of 700 days and average inhalation volume per day of $0.04 \mathrm{~m}^{3}$ ), and this dose seemed to be adequate for assessing a life time effect of suspended particles in urban air. On the other hand, administration of 2010 elevated the mutant frequency dose-dependently, but this elevation was statistically insignificant. We measured the weight of lung at the sampling (14 days after the administration of extract). The lung weight of mice was shown to significantly increase by administration of $0.15 \mathrm{mg}, 0.3 \mathrm{mg}$ and $0.6 \mathrm{mg}$ of 1990 extract
$(0.131 \pm 0.009 \mathrm{~g}(P<0.05), 0.134 \pm 0.006 \mathrm{~g}(P<0.01)$ and $0.146 \pm 0.004(P<0.01)$, respectively) comparing to the control $(0.117 \pm 0.002 \mathrm{~g})$ (Additional file 2: Figure S1B), and similar significant increase in the lung weight was observed by administration of $0.3 \mathrm{mg}$ and $0.6 \mathrm{mg}$ of 2010 extract $(0.149 \pm 0.010 \mathrm{~g}(P<0.01)$ and $0.171 \pm$ $0.006 \mathrm{~g}(P<0.01)$, respectively vs. the control, $0.123 \pm$ $0.010 \mathrm{~g}$ ) (Additional file 2: Figure S1C), while the lung weight was not altered by the administration of 1980 extract (Additional file 2: Figure $\mathrm{S} 1 \mathrm{~A}$ ). The relative lung 
weight was also significantly increased by the administration of 1990 extract and 2010 extract (Additional file 2: Figure $1 \mathrm{H}$ and I).

We examined histopathological changes in the lung of mice by the administration of 2010 extract (Additional file 3: Figure S2). Atypical hypertrophy and hyperplasia of bronchiolar epithelial cells, and bronchiolization were observed at bronchioalveolar junction in the lungs by administration of the extract, and were more severe at a dose of $0.6 \mathrm{mg}$ (Additional file 3: Figure S2D). A marked increase of enlarged alveolar macrophages was also observed in alveoli in the lungs by administration of the extract, and inflammatory cells such as neutrophils and eosinophils were retained in capillary and interstitial tissues especially at a dose of $0.6 \mathrm{mg}$. (Additional file 3: Figure S2D and S2E), Similar histopathological changes were possibly induced in 1990 extract-administered lungs, of which weight was increased by the administration. But, edema was not shown in the lungs of extract-administered mice. Already, exacerbation of inflammation associated with increase in lung weight was shown in mouse lungs by instillation of diesel exhaust particles [34, 35]. These observations suggest that inflammation and cell proliferation were enhanced in the lungs by the administration of extract.

Because the 6-TG-resistant mutants may have included identical mutants generated via clonal expansion enhanced by cell proliferation, we also estimated total mutation frequency. The increase in total mutation frequency (i.e., the frequency at which independent mutants arose) was also significantly increased in mice administered the 1990 extract at a dose of $0.15 \mathrm{mg}$ compared with that in mice administered vehicle control $(0.64 \times$ $10^{-5}$ vs. $0.35 \times 10^{-5}$ ) (Fig. 1e). In mice administered the 2010 extract, both total mutant frequency and total mutation frequency were dose-dependently increased; however, only the increase in total mutation frequency induced by administration of $0.3 \mathrm{mg}$ of the 2010 extract was statistically significant compared with that in mice administered vehicle control $\left(0.73 \times 10^{-5}, 1.6\right.$-times higher than vehicle control $\left(0.45 \times 10^{-5}\right)$; Fig. $1 \mathrm{c}$ and $\left.\mathrm{f}\right)$.

\section{Types of mutation induced by the TSP extract}

To determine the types of mutations induced by the extracts, we isolated 6-TG-resistant gpt mutants from mice administered the extracts and sequenced the mutant DNA. As shown in Table 2, G-to-A transition was the most common base substitution in mice treated with the 1980, 1990, and 2010 extracts (40\% [40/100], 44\% [27/61], and 39\% [41/106], respectively), as well as in vehicle control mice (44\% [41/93]), which is consistent with previous results from an exposure study of diesel exhaust particles in gpt delta mice [25] .

However, administration of the 1990 extract significantly increased the G-to- $T$ transversion frequency compared with that in mice administered vehicle control (Fig. 1b and e). At a dose of $0.15 \mathrm{mg}$, both the mutant and mutation frequency of G-to-T transversion were significantly elevated to $0.28 \times 10^{-5}$ and $0.25 \times 10^{-5}$, respectively, which were values comparable to those for G-to-A transition, but the elevation of G-to- $\mathrm{T}$ transversion was not seen at a dose of $0.3 \mathrm{mg}$ or $0.6 \mathrm{mg}$. In mice administered a dose of $0.3 \mathrm{mg}$, instead of G-to-T transversion, deletions and insertions (both $14 \%$ [4/28]) were found to contribute to the increase in total mutant and total mutation frequency (Table 2).

Administration of the 2010 extract at a dose of $0.3 \mathrm{mg}$ induced a significant increase in the frequency of G-to-A transition mutations $\left(0.39 \times 10^{-5}\right)$ compared with the control $\left(0.16 \times 10^{-5}\right)$. However, at a dose of $0.6 \mathrm{mg}$, G-to-T transversion became the most common mutation $(41 \%$ [26/64], Table 2), and the mutation frequency of this base substitution $\left(0.30 \times 10^{-5}\right)$ was significantly increased compared with the control $\left(0.10 \times 10^{-5}\right)$ to the same level as G-to-A transition (Fig. 1f). No significant changes were observed in the frequency of A-to-T transversion by the administration of 1990 extract or 2010 extract (Fig. 1).

G-to- $\mathrm{T}$ transversion is a landmark base substitution induced by oxidative stress [36, 37], which implies that the observed increases in the frequency of in vivo mutations in the lungs of the gpt delta mice may be driven by reactive oxygen species generated by compounds contained in the extracts.

\section{Mutations induced by 1,2-NQ}

Next, we examined whether a reactive oxygen speciesgenerating compound had the ability to induce G-to-T transversion mutations in the lungs of gpt delta mice, by using 1,2-NQ as a representative compound contained in diesel exhaust [29, 38]. Two-times intratracheal administration of 1,2-NQ at an interval of 2 weeks and at a dose of 300 or $600 \mathrm{ng}$ did not significantly alter total mutant frequency in the mice (Fig. 2 and Additional file 4: Table S2). The most common mutation in the mice administered 600 ng 1,2-NQ was G-to-T transversion (36\% [17/47]), whereas that in the vehicle control mice was G-to-A transition (47\% [16/34]) (Additional file 5: Table S3). Thus, the mutant frequency of G-to-T transversion was significantly increased in mice administered $600 \mathrm{ng} 1,2-\mathrm{NQ}$ compared with that in mice administered vehicle control $\left(0.19 \times 10^{-5}\right.$ vs. $0.06 \times 10^{-5}$; Fig. 2$)$, indicating that the reactive oxygen species-generating compound 1,2-NQ induced G-to- $\mathrm{T}$ transversion mutations in the lungs of the mice.

\section{Characterization of mutation hotspots on the gpt gene induced by the TSP extracts}

Sequencing of the 6-TG-resistant mutants revealed that administration of the extracts induced mutations at 
several mutation hotspots on the gpt gene, which we defined as mutation foci identified in three or more mice (Additional file 6: Figure S3A-C; summarized in Fig. 3) [25]. In the mice administered the 1990 extract at a dose of $0.3 \mathrm{mg}$ (see Additional file 6: Figure S3B for the positions of the mutations on the gpt gene), nucleotide 110 was identified as a hotspot for G-to-A transition mutations. In the mice administered the 2010 extract (see Additional file 6: Figure S3C for the positions of the mutations on the gpt gene), nucleotides 64. (dose, $0.6 \mathrm{mg}$ ), 110 (dose, $0.3 \mathrm{mg}$ ), and 115 (doses, 0.15 and $0.3 \mathrm{mg}$ ) were identified as hotspots for G-to-A transition mutations. On nucleotides 64,110 , and 115 , spontaneous mutations were already shown to be frequently induced [39, 40], and actually G-to-A transitions arose on these nucleotides in all control groups (except nucleotide 64 in the control for 1990 extract) in this study (Fig. 3). Since G-to-A transitions were identified on nucleotide 115 in more than three mice in the control mice (for the 1980 and 1990 extracts), we identified nucleotides 64 and 110 as hotspots induced by the extracts of TSP. These results suggest that exposure to the 1990 and 2010 extracts accelerated the induction of spontaneous mutation. Furthermore, nucleotide 406 was identified as a hotspot for G-to-T transversion mutations in the mice administered the 2010 extract at a dose of $0.6 \mathrm{mg}$ (see Additional file 6: Figure S3C for the positions of the mutations on the gpt gene). Nucleotide 406 was not identified as a position that frequently spontaneous mutations arose, and G-to-T transition mutations were also detected at this nucleotide in mice administered the 1980 and 1990 extracts (Additional file 6: Figure S3A and S3B; summarized in Fig. 3). In the mice administered the 1980 extract, nucleotides 64 and 110 were identified as hotspots for G-to-A transition mutations at a dose of $0.6 \mathrm{mg}$.

\section{Discussion}

Here, we report that extracts made from TSP collected within the Tokyo metropolitan area in 1980, 1990, and 2010 induced mutagenesis in the lungs of gpt delta mice after intratracheal instillation. This study is first report to examine the chronological change in in vivo mutagenicity of airborne particles in past 40 years using archaeological specimen, but our study has a limitation that some compounds, such as ROS-generating compounds, were possibly degraded during storage for over 30 years even if collected airborne particles were kept in $-80^{\circ} \mathrm{C}$.

The 1990 extract significantly elevated both total mutant frequency and total mutation frequency at a dose of $0.15 \mathrm{mg}$, whereas only total mutant frequency was increased at a dose of $0.3 \mathrm{mg}$ (Fig. $1 \mathrm{~b}$ and e). In contrast, administration of the 2010 extract induced an increase in total mutation frequency, but not total mutant frequency, at a dose of $0.3 \mathrm{mg}$ (Fig. 1c and f). Our previous observations showed

Table 2 Mutation spectra of gpt mutations in the lungs of gpt delta mice administered the extracts

\begin{tabular}{|c|c|c|c|c|c|c|c|c|c|c|c|c|c|c|c|c|}
\hline \multirow{3}{*}{$\begin{array}{l}\text { Type of } \\
\text { mutation in gpt }\end{array}$} & \multirow{2}{*}{\multicolumn{2}{|c|}{$\begin{array}{l}\text { Control } \\
\text { All }(1980+1990+ \\
2010) \\
\end{array}$}} & \multicolumn{10}{|l|}{1980} & \multicolumn{4}{|l|}{1990} \\
\hline & & & \multicolumn{2}{|l|}{ control } & \multicolumn{2}{|l|}{$0.3 \mathrm{mg}$} & \multicolumn{2}{|l|}{$0.6 \mathrm{mg}$} & \multicolumn{2}{|l|}{$0.9 \mathrm{mg}$} & \multicolumn{2}{|c|}{ All $(0.3+0.6+0.9)$} & \multicolumn{2}{|l|}{ control } & \multicolumn{2}{|l|}{$0.15 \mathrm{mg}$} \\
\hline & Number & $\%$ & Number & $\%$ & Number & $\%$ & Number & $\%$ & Number & $\%$ & Number & $\%$ & Number & $\%$ & Number & $\%$ \\
\hline \multicolumn{17}{|l|}{ Base substitution } \\
\hline \multicolumn{17}{|l|}{ Transition } \\
\hline $\mathrm{G}: \mathrm{C} \rightarrow \mathrm{A}: \mathrm{T}$ & 41 & 44 & 18 & 40 & 12 & 48 & 23 & 43 & 5 & 23 & 40 & 40 & 6 & 46 & 8 & 33 \\
\hline (CpG site) & (29) & & (12) & & (8) & & (14) & & (0) & & (22) & & (4) & & (5) & \\
\hline $\mathrm{A}: \mathrm{T} \rightarrow \mathrm{G}: \mathrm{C}$ & 9 & 10 & 4 & 9 & 1 & 4 & 6 & 11 & 2 & 9 & 9 & 9 & 2 & 15 & 1 & 4 \\
\hline \multicolumn{17}{|l|}{ Transversion } \\
\hline $\mathrm{G}: \mathrm{C} \rightarrow \mathrm{T}: \mathrm{A}$ & 17 & 18 & 9 & 20 & 7 & 28 & 9 & 17 & 6 & 27 & 22 & 22 & 2 & 15 & 9 & 38 \\
\hline $\mathrm{G}: \mathrm{C} \rightarrow \mathrm{C}: \mathrm{G}$ & 1 & 1 & 0 & 0 & 1 & 4 & 2 & 4 & 1 & 5 & 4 & 4 & 0 & 0 & 1 & 4 \\
\hline $\mathrm{A}: \mathrm{T} \rightarrow \mathrm{T}: \mathrm{A}$ & 2 & 2 & 0 & 0 & 0 & 0 & 0 & 0 & 2 & 9 & 2 & 2 & 1 & 8 & 2 & 8 \\
\hline $\mathrm{A}: \mathrm{T} \rightarrow \mathrm{C}: \mathrm{G}$ & 6 & 6 & 4 & 9 & 1 & 4 & 3 & 6 & 0 & 0 & 4 & 4 & 0 & 0 & 1 & 4 \\
\hline \multicolumn{17}{|l|}{ Deletion } \\
\hline 1 & 15 & 16 & 8 & 18 & 2 & 8 & 7 & 13 & 3 & 14 & 12 & 12 & 2 & 15 & 2 & 8 \\
\hline$\geq 2$ & 1 & 1 & 1 & 2 & 0 & 0 & 1 & 2 & 0 & 0 & 1 & 1 & 0 & 0 & 0 & 0 \\
\hline Insertion & 1 & 1 & 1 & 2 & 1 & 4 & 1 & 2 & 2 & 9 & 4 & 4 & 0 & 0 & 0 & 0 \\
\hline Other & 0 & 0 & 0 & 0 & 0 & 0 & 1 & 2 & 1 & 5 & 2 & 2 & 0 & 0 & 0 & 0 \\
\hline Total & 93 & 100 & 45 & 100 & 25 & 100 & 53 & 100 & 22 & 100 & 100 & 100 & 13 & 100 & 24 & 100 \\
\hline
\end{tabular}

'All' indicates combined data of mice treated with the different concentrations of extract. The column of 'All $(1980+1990+2010)$ ' indicates the sum of number of each mutation in the control for 1980, 1990 and 2010, and the percentage of each mutation 
Table 2 Mutation spectra of gpt mutations in the lungs of gpt delta mice administered the extracts (Continued)

\begin{tabular}{|c|c|c|c|c|c|c|c|c|c|c|c|c|c|c|c|c|}
\hline \multirow{3}{*}{$\begin{array}{l}\text { Type of } \\
\text { mutation in gpt }\end{array}$} & \multicolumn{6}{|l|}{1990} & \multicolumn{10}{|l|}{2010} \\
\hline & \multicolumn{2}{|l|}{$0.3 \mathrm{mg}$} & \multicolumn{2}{|l|}{0.6 mg } & \multicolumn{2}{|c|}{ All $(0.15+0.3+0.6)$} & \multicolumn{2}{|l|}{ control } & \multicolumn{2}{|l|}{$0.15 \mathrm{mg}$} & \multicolumn{2}{|l|}{$0.3 \mathrm{mg}$} & \multicolumn{2}{|l|}{$0.6 \mathrm{mg}$} & \multicolumn{2}{|c|}{ All $(0.15+0.3+0.6)$} \\
\hline & Number & $\%$ & Number & $\%$ & Number & $\%$ & Number & $\%$ & Number & $\%$ & Number & $\%$ & Number & $\%$ & Number & $\%$ \\
\hline $\mathrm{G}: \mathrm{C} \rightarrow \mathrm{A}: \mathrm{T}$ & 14 & 50 & 5 & 56 & 27 & 44 & 17 & 49 & 7 & 41 & 14 & 56 & 20 & 31 & 41 & 39 \\
\hline (CpG site) & (12) & & (3) & & (20) & & (13) & & (6) & & (10) & & (12) & & (28) & \\
\hline $\mathrm{A}: \mathrm{T} \rightarrow \mathrm{G}: \mathrm{C}$ & 1 & 4 & 0 & 0 & 2 & 3 & 3 & 9 & 1 & 6 & 1 & 4 & 2 & 3 & 4 & 4 \\
\hline \multicolumn{17}{|l|}{ Transversion } \\
\hline $\mathrm{G}: \mathrm{C} \rightarrow \mathrm{T}: \mathrm{A}$ & 2 & 7 & 1 & 11 & 12 & 20 & 6 & 17 & 4 & 24 & 5 & 20 & 26 & 41 & 35 & 33 \\
\hline $\mathrm{G}: \mathrm{C} \rightarrow \mathrm{C}: \mathrm{G}$ & 1 & 4 & 1 & 11 & 3 & 5 & 1 & 3 & 0 & 0 & 0 & 0 & 1 & 2 & 1 & 1 \\
\hline $\mathrm{A}: \mathrm{T} \rightarrow \mathrm{T}: \mathrm{A}$ & 0 & 0 & 1 & 11 & 3 & 5 & 1 & 3 & 0 & 0 & 0 & 0 & 0 & 0 & 0 & 0 \\
\hline $\mathrm{A}: \mathrm{T} \rightarrow \mathrm{C}: \mathrm{G}$ & 2 & 7 & 0 & 0 & 3 & 5 & 2 & 6 & 0 & 0 & 0 & 0 & 1 & 2 & 1 & 1 \\
\hline \multicolumn{17}{|l|}{ Deletion } \\
\hline 1 & 4 & 14 & 0 & 0 & 6 & 10 & 5 & 14 & 4 & 24 & 4 & 16 & 9 & 14 & 17 & 16 \\
\hline$\geq 2$ & 0 & 0 & 1 & 11 & 1 & 2 & 0 & 0 & 0 & 0 & 1 & 4 & 1 & 2 & 2 & 2 \\
\hline Insertion & 4 & 14 & 0 & 0 & 4 & 7 & 0 & 0 & 1 & 6 & 0 & 0 & 2 & 3 & 3 & 3 \\
\hline Other & 0 & 0 & 0 & 0 & 0 & 0 & 0 & 0 & 0 & 0 & 0 & 0 & 2 & 3 & 2 & 2 \\
\hline Total & 28 & 100 & 9 & 100 & 61 & 100 & 35 & 100 & 17 & 100 & 25 & 100 & 64 & 100 & 106 & 100 \\
\hline
\end{tabular}

accumulation of DNA adducts in the lungs of rats inhaled to urban air [20]. The observed increases in mutation frequency reported here suggest that DNA-adduct formation induced by urban air resulted mainly in increases in base substitutions. However, since the administration of extracts induces mutations in gpt gene on the hotspots where

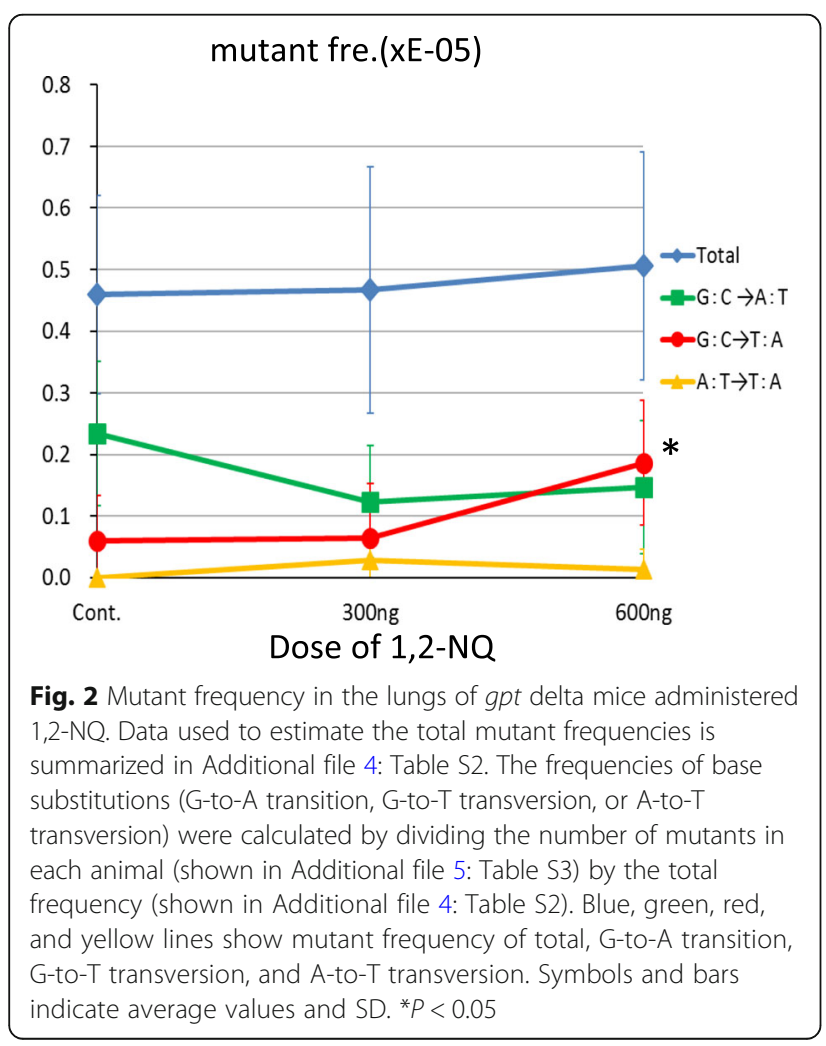

spontaneous mutations arose frequently, cell proliferation accelerated by the extracts also possibly contributes to the increase in in vivo mutagenesis.

Among the three extracts, the 1990 extract was the most potent inducer of in vivo mutation in the murine lung (Table 3); the in vivo mutagenic potency (defined in the section of gpt mutant frequency in Materials and Methods) was estimated as $1.9 \times 10^{-5} / \mathrm{mg}$ extract based on average mutation frequency $\left(0.64 \times 10^{-5}\right)$ at a dose that the significant increase was shown $(0.15 \mathrm{mg})$. In contrast, the in vivo mutagenic potency of the 2010 sample was estimated to be $0.93 \times 10^{-5} / \mathrm{mg}$ extract, based on average mutation frequency $\left(0.73 \times 10^{-5}\right)$ at a dose that the significant increase was shown $(0.3 \mathrm{mg})$ lower than that of the 1990 extract. Even though significant increase in mutation frequency was not observed by administration of 1980 extract, the in vivo mutagenic potency of this extract was tentatively calculated to be $0.8 \times 10^{-5} / \mathrm{mg}$ lower than that of the 1990 extract based on the average mutation frequency at the dose of $0.3 \mathrm{mg}$ $\left(0.64 \times 10^{-5}\right)$ (Fig. 1d). Thus, the 1990 extract had approximately 2.0-times the mutagenicity of 2010 extract, and 2.4-times higher mutagenicity than the 1980 extract.

In this study, we measured the concentration of TSP collected at the sampling points. The estimated concentration of TSP in our study decreased gradually as the sampling year increased $\left(0.095,0.080\right.$, and $0.059 \mathrm{mg} / \mathrm{m}^{3}$ in 1980, 1990, and 1999, respectively) at the Shirokanedai sampling point; and the concentration of TSP at the Kagurazaka sampling point in $2010\left(0.036 \mathrm{mg} / \mathrm{m}^{3}\right)$ was lower compared with Shirokanedai sampling point (Table 3). In addition, we examined the in vitro 


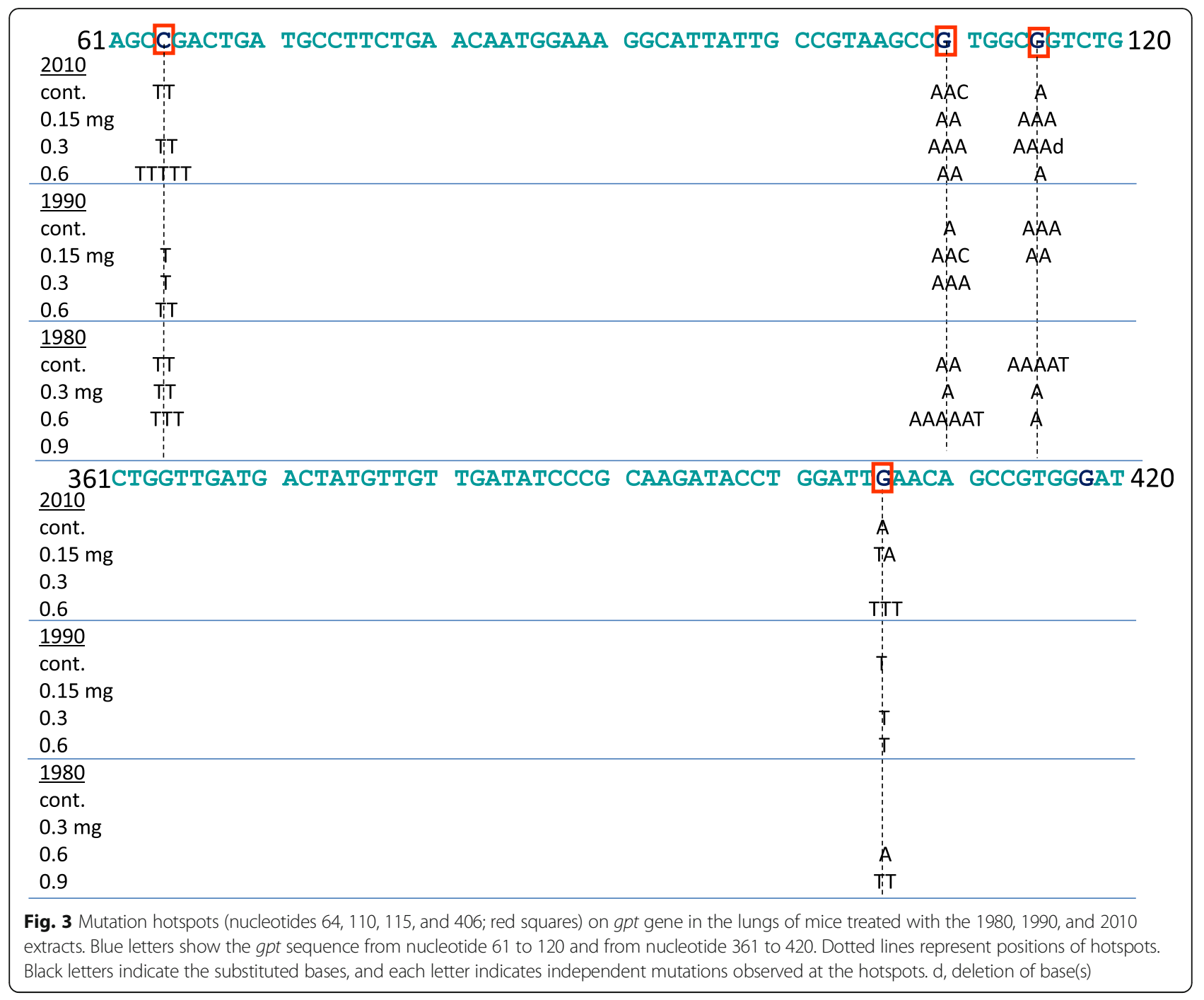

mutagenicity of extracts made from TSP collected from 1980 to 2001 by the Ames test using Salmonella typhimurium strains TA98 and TA100 with or without S9 mixture [41], and showed that the in vitro mutagenicity of extract assayed by TA100 (-S9) and TA98(+S9) was a similar level between 1980 extract and 1990 extract (in vitro mutagenicity in 1990: 576 and 527 revertants/mg

Table 3 Mutagenicity and concentration of TSP in Tokyo metropolitan area in 1980, 1990 and 2010

\begin{tabular}{llll}
\hline Sampling time & $\begin{array}{l}\text { In vivo mutagenic } \\
\text { potency }^{\mathrm{a}}\end{array}$ & $\begin{array}{l}\text { Concentration } \\
\text { of TSP }^{\mathrm{b}}\end{array}$ & $\begin{array}{l}\text { In vitro mutagenic } \\
\text { potency }^{\mathrm{c}}\end{array}$ \\
\hline 1980 & $0.8 \times 10^{-5}$ & 0.095 & 1302 \\
1990 & $1.9 \times 10^{-5}$ & 0.080 & 870 \\
2010 & $0.93 \times 10^{-5}$ & 0.036 & \\
\hline
\end{tabular}

apt average mutation frequency per mg extract

${ }^{\mathrm{b}} \mathrm{mg} / \mathrm{m}^{3}$

${ }^{C} \mathrm{His}^{+}$revertants per mg extract in TA98 without S9 (representative of Ames tests). Data from the reference [38] extract; in vitro mutagenicity in 1980: 554 and 517 revertants/mg extract using TA100 (-S9) and TA98 (+S9), respectively) but that assayed by TA100 (+S9) and TA98 (-S9) was higher in 1980 extract than 1990 extract (in vitro mutagenicity in 1990: 390 and 870 revertants/mg extract; in vitro mutagenicity in 1980: 700 and 1302 revertants/mg extract using TA100 (+S9) and TA98 (-S9), respectively) (Table 3 ). The results described above suggest that in the present study the 1990 extract contained higher concentrations of components that induced in vivo mutations than did the 1980 extract. For example, $\mathrm{BaP}$, a potent mutagen in ambient air, was expected to contribute to the in vivo mutagenicity of the 1990 extract, but the concentration of $\mathrm{BaP}$ in the $1990 \mathrm{ex}$ tract (15.4 $\mathrm{ng} \mathrm{BaP}$ contained in $1 \mathrm{mg}$ of this extract, see Table 1) was assumed to be ignorable for in vivo mutagenicity of this extract; because the in vivo mutagenic potency of $\mathrm{BaP}$ was estimated to be $1.5 \times 10^{-5} / \mathrm{mg}$ [32], the in vivo mutagenic potency of $15.4 \mathrm{ng} \mathrm{BaP}$ was 
calculated to be approximately $2.3 \times 10^{-10}$, which was evaluated as $1.2 \times 10^{-5}$ part of the in vivo mutagenic potency of 1990 extract $\left(1.9 \times 10^{-5} / \mathrm{mg}\right.$ extract $)$.

Further studies are needed to elucidate why the 1990 extract had the highest in vivo mutagenicity among the extracts examined in the present study. However, the lower in vivo mutagenicity of the 2010 extract is possibly the result of environmental protection measures implemented in the Greater Tokyo Area in the 2000s to reduce diesel engine emissions and the concentrations of TSP in urban air [42]. We revealed here chronological changes in in vivo mutagenic potency of extract made from TSP by a single intratracheal administration, however, in vivo mutagenesis induced by repeated dosing of extract also needs to be analyzed for assessing the chronic effect.

The in vivo mutagenicity of genotoxic chemicals is related to their carcinogenicity. For example, we have previously shown that the carcinogenicity of genotoxic compounds (median toxic dose $\left[\mathrm{TD}_{50}\right]$, defined here as lifetime daily dose in $\mathrm{mg} / \mathrm{kg} /$ day that induces tumorigenesis in half of the test animals) was correlated with in vivo mutagenicity (total dose [mg per kg-body weight] after administration of multiple doses of test substance per induced mutant frequency $\times 10^{5}$ ) [43] as a following equation.

$\log \left[\right.$ total dose per (induced mutant frequency $\left.\left.\times 10^{5}\right)\right]$

$$
=1.16719 \times \log \mathrm{TD}_{50}-0.023
$$

So, as a case study for adopting this correlation we derived, we used evaluate the carcinogenicity of 1990 extract from the in vivo mutagenicity, although in the present study we estimated in vivo mutagenicity after only a single intratracheal instillation of the extracts. In vivo mutagenicity (total dose of extract per induced mutant frequency $\times 10^{5}$ ) was estimated as $14.7 \mathrm{mg} / \mathrm{kg}$, which was calculated from total dose $(5 \mathrm{mg} / \mathrm{kg}$ body weight; dose [0.15 mg] divided by $0.03 \mathrm{~kg}$ [assumed average body weight of a male mouse]) and induced mutant frequency $\times 10^{5}(0.34)$ at a dose of $0.15 \mathrm{mg}$. This value corresponds to a $\mathrm{TD}_{50}$ value of $5.2 \mathrm{mg} / \mathrm{kg} / \mathrm{day}$ [43]. If the body weight of a male mouse is $0.03 \mathrm{~kg}$ [44], then the daily intake of extract corresponding to the $\mathrm{TD}_{50}$ value is estimated to be $0.156 \mathrm{mg} /$ day. And if the daily inhalation volume of a male mouse is $0.04 \mathrm{~m}^{3}$ [44], then the concentration of extract in air corresponding to the daily intake for the $\mathrm{TD}_{50}$ value is equal to $3.9 \mathrm{mg} / \mathrm{m}^{3}$, which is approximately 370-times the concentration of extract in the air at the sampling point in 1990 $\left(0.0105 \mathrm{mg} / \mathrm{m}^{3}\right)$.

Our mutation spectrum analysis showed that G-to-A transition was the most common base substitution in the lungs of the gpt delta mice administered the extracts (Table 2 and Fig. 1). The reason that the mutant/mutation frequency of G-to-A transition was elevated by the administration of extracts is unknown. But, decrease in mismatch repair may contribute to the increase in occurrence of G-to-A transitions in the extract-instilled mice [45]. Another possibility is that DNA cytidine deaminase, which catalyzes the conversion of cytosine to uracil [46], is activated in the lungs, causing to lead G:U mispair formation and hence mutation of $\mathrm{G}: \mathrm{C}$ to A:T [47]. Administration of the extracts increased the frequency of not only G-to-A transition but also of G-to-T transversion, which is a landmark mutation induced by oxidative stress $[36,37]$ via formation of 8-oxo-deoxyguanine [48], and is a common mutation on TP53 gene in human lung cancer [13]. G-to-T transversion was the most common mutation in mice administered the 1990 extract at a dose of $0.15 \mathrm{mg}$ or the 2010 extract at a dose of $0.6 \mathrm{mg}$, suggesting that the extract contained oxidative-stress-generating components. To confirm this possibility, 1,2-NQ (a representative generator of oxidative stress that is present in diesel exhaust and urban air $[29,38])$ was instilled into the lungs of gpt delta mice, and the mutation spectrum was determined (Fig. 2). Although the total mutant frequency remained the same compared with control after instillation of 1,2-NQ at the doses we examined, G-to-T transversion, not G-to-A transition, was the most common base substitution in the 1.2-NQ-instilled lung at a dose of $600 \mathrm{ng}$. This suggests that oxidative stress-generating compounds, such as 1,2-NQ, increase at least in part, the mutagenicity and possibly the carcinogenicity of inhaled urban air.

It is well known that mutations are not uniformly induced on the gpt gene. The 1980, 1990, and 2010 extracts induced hotspots at nucleotides 64 and 110 for G-to-A transition mutations (Fig. 3). Because nucleotides 64 and 110 are part of $\mathrm{CpG}$ sites where spontaneous mutations are known to occur frequently [39, 40], this suggests that the in vivo mutagenicity of extracts used in the present study was partly caused by accelerated spontaneous mutation. Previously, we showed that nucleotides 64 and 110 were hotspots for G-to-A transition mutations in the lungs of mice exposed to diesel exhaust via inhalation, diesel exhaust particles via instillation, or diesel-exhaust-particle extract via instillation [25], as well as in the lungs of mice exposed to 1,6-dinitropyrene, a potent mutagen contained in diesel exhaust particles, via instillation [33], suggesting that this compound and related compounds contribute to the induction of in vivo mutations by TSP. Similarly, nucleotide 406 is a hotspot for G-to- $\mathrm{T}$ transversion mutations induced by the extracts examined in the present study and also by inhalation to diesel exhaust or instillation of diesel exhaust particles or their extract; however, nucleotide 406 is not part of a CpG site and G-to-T transversion at this nucleotide may have specifically been induced via oxidative stress generated by compounds contained in the sampled 
urban air. Together, our results indicate that exposure to TSP extract induced the same mutation hotspots as those identified in the murine lung after exposure to diesel exhaust and its components such as 1,6-dinitropyrene.

\section{Conclusions}

Our analysis of the mutagenesis induced by extracts made from TSP collected within the Tokyo metropolitan area suggests that urban air contains compounds that induce in vivo mutations via the same mechanism that components of diesel exhaust induce in vivo mutations. In addition, the present study shows that the gpt delta transgenic rodent in vivo mutation assay system is a useful tool for the biomonitoring of environmental mutagens, especially when they are present together with other chemicals.

\section{Additional files}

\section{Additional file 1: Table S1. Mutant and mutation frequencies in the} lungs of gpt delta mice administered the extracts. (XLSX $15 \mathrm{~kb}$ )

Additional file 2: Figure S1. Alterations in the body weight ( $A, B$ and $C$ ), the lung weight $(D, E$ and $F$ ) and relative lung weight (weight of lung / body weight $\left(\times 10^{-3}\right)$ by the administration of extracts (1980 extract, A, D and G; 1990 extract B, E and H; and 2010 extract, C, F and I). Horizontal axes indicate the dose of extract (mg). ${ }^{*} P<0.05,{ }^{* *} P<0.01$ and ${ }^{* * *} P<0.001$ comparing to the control. (XLSX $64 \mathrm{~kb})$

Additional file 3: Figure S2. H \& E staining of lung tissue. (A) the lung of control mouse and the lung of mouse administered 2010 extract at a dose of $0.15 \mathrm{mg}(\mathrm{B}), 0.3 \mathrm{mg}(\mathrm{C})$ and $0.6 \mathrm{mg}(\mathrm{D})$. Arrows in panels $\mathrm{B}, \mathrm{C}$ and $\mathrm{D}$ indicate bronchiolization at bronchioalveolar junction. (E) indicates enlarged photo of squared part in panel D. Blue, black and red arrow in panel E indicates alveolar macrophage, neutrophil and eosinophil. Scale bars; $100 \mu \mathrm{m}$. (PPTX 22998 kb)

Additional file 4: Table S2. Mutant frequency in the lungs of gpt delta mice administered 1,2-NQ. (XLSX $10 \mathrm{~kb}$ )

Additional file 5: Table S3. Mutation spectra of gpt mutations in the lungs of gpt delta mice administered 1,2-NQ. 'All' indicates combined data of mice treated with 1,2-NQ at a dose of 300 or $600 \mathrm{ng}$. (XLSX $11 \mathrm{~kb}$ )

Additional file 6: Figure S3. Positions of mutations on the gpt gene in the lungs of extract-treated mice and vehicle control mice. Panels A, B, and $C$ show the mutations induced in the lungs of mice treated with the 1980, 1990, and 2010 extracts, respectively. ID is the animal identification number, which corresponds to the numbers shown in Additional file 1: Table S1. The letters A, G, T, and C indicate base substitutions, and the number of characters in brackets indicates the number of clonal mutant. Arrows indicate the position of insertion of base(s). d, deletion of base(s). (ZIP $134 \mathrm{~kb})$

\section{Acknowledgements}

Preparation of slices from fixed lung tissues and HE stain for histopathological examination were performed by DIMS Institute of Medical Science (Komaki, Japan). We thank Dr. Akiko Furuyama for her helpful suggestion for histopathological examination, and Dr. Noriyuki Suzuki (National Institute for Environmental Studies) for his encouraging this study.

\section{Funding}

This study was supported by Grant-in-Aid for Scientific Research (B) (\#25293034) from Japan Society for the Promotion of Science.

\section{Availability of data and materials}

The datasets used and analyzed during the current study are available from the corresponding author on reasonable request.

\section{Authors' contributions}

YA was a major contributor in designing this study and writing the manuscript. DN collected TSP, performed preparation of the extract from TSP and Ames assay, and revised the manuscript critically. MichiyoM performed animal experiments and gpt assay and analyzed the data. MY performed the analysis of PAH. MichiM performed animal experiments and managed the laboratory. RY performed intratracheal administration of specimen. SG collected TPS and kept them for a few decades. KM and TN established gpt delta rodent assay system, and revised the manuscript critically. All authors read and approved the final manuscript.

\section{Ethics approval}

The animal studies in this report were approved by the Animal Care and Use Committee of National Institute for Environmental Studies.

\section{Consent for publication}

Not applicable.

\section{Competing interests}

The authors declare that they have no competing interests.

\section{Publisher's Note}

Springer Nature remains neutral with regard to jurisdictional claims in published maps and institutional affiliations.

\section{Author details}

${ }^{1}$ National Institute for Environmental Studies, Center for Health and Environmental Risk Research, 16-2 Onogawa, Tsukuba, Ibaraki 305-8506, Japan. ${ }^{2}$ Azabu University, School of Life and Environmental Science, Sagamihara, Japan. ${ }^{3}$ National Institute of Health Sciences, Division of Genetics and Mutagenesis, Kawasaki-ku, Japan.

Received: 11 August 2018 Accepted: 30 October 2018

Published online: 29 November 2018

\section{References}

1. Silva RA, Adelman Z, Fry MM, West JJ. The impact of individual anthropogenic emissions sectors on the global burden of human mortality due to ambient air pollution. Environ Health Perspect. 2016;124:1776.

2. Pope CA 3rd, Burnett RT, Thun MJ, Calle EE, Krewski D, Ito K, Thurston GD. Lung cancer, cardiopulmonary mortality, and long-term exposure to fine particulate air pollution. JAMA. 2002;287(9):1132-41.

3. Laden F, Schwartz J, Speizer FE, Dockery DW. Reduction in fine particulate air pollution and mortality: extended follow-up of the Harvard six cities study. Am J Respir Crit Care Med. 2006;173(6):667-72.

4. Katanoda K, Sobue T, Satoh H, Tajima K, Suzuki T, Nakatsuka H, Takezaki T, Nakayama T, Nitta H, Tanabe K, et al. An association between long-term exposure to ambient air pollution and mortality from lung cancer and respiratory diseases in Japan. J Epidemiol. 2011;21(2):132-43.

5. Patel MM, Quinn JW, Jung KH, Hoepner L, Diaz D, Perzanowski M, Rundle A, Kinney PL, Perera FP, Miller RL. Traffic density and stationary sources of air pollution associated with wheeze, asthma, and immunoglobulin E from birth to age 5 years among New York City children. Environ Res. 2011; 111(8):1222-9.

6. Tanaka M, Aoki Y, Takano H, Fujitani Y, Hirano S, Nakamura R, Sone Y, Kiyono $\mathrm{M}$, Ichinose $\mathrm{T}$, Itoh $\mathrm{T}$, et al. Effects of exposure to nanoparticle-rich or -depleted diesel exhaust on allergic pathophysiology in the murine lung. J Toxicol Sci. 2013;38(1):35-48.

7. Inomata Y, Kajino M, Sato K, Ohara T, Kurokawa J, Ueda H, Tang N, Hayakawa K, Ohizumi T, Akimoto H. Source contribution analysis of surface particulate polycyclic aromatic hydrocarbon concentrations in northeastern Asia by source-receptor relationships. Environ Pollut (Barking, Essex: 1987). 2013;182:324-34.

8. Zhang Q, Jiang X, Tong D, Davis SJ, Zhao H, Geng G, Feng T, Zheng B, Lu Z, Streets DG, et al. Transboundary health impacts of transported global air pollution and international trade. Nature. 2017;543(7647):705-9.

9. Ngo NS, Bao X, Zhong N. Local pollutants go global: the impacts of intercontinental air pollution from China on air quality and morbidity in California. Environ Res. 2018;165:473-83. 
10. European communities. Ambient Air Pollution by Polycyclic Aromatic Hydrocarbons (PAH), Position Paper. 2001. [http://ec.europa.eu/ environment/air/pdf/pp_pah.pdf]. Accessed 12 Nov 2018.

11. European Communities. Ambient Air Pollution by Polycyclic Aromatic Hydrocarbons (PAH), Position Paper Annexes. 2001. [http://ec.europa.eu/ environment/air/pdf/annex_pah.pdf]. Accessed 12 Nov 2018.

12. IARCMHO. Some Non-heterocyclic Polycyclic Aromatic Hydrocarbons and Some Related Exposures, IARC Monographs on the Evaluation of Carcinogenic Risks to Human, vol. 92. Lyon; 2010.

13. IARC/WHO. Outdoor air pollution, IARC Monographs on the Evaluation of Carcinogenic Risks to Human, vol. 105. Lyon; 2015.

14. Claxton LD, Matthews PP, Warren SH. The genotoxicity of ambient outdoor air, a review: Salmonella mutagenicity. Mutat Res. 2004;567(2-3):347-99.

15. Claxton LD, Woodall GM Jr. A review of the mutagenicity and rodent carcinogenicity of ambient air. Mutat Res. 2007;636(1-3):36-94.

16. Matsumoto M, Ando M, Tamura K. Difference of mutagenic activity of airborne particulates by particle size: assay by the Salmonella microsuspension procedure. Jpn J Toxicol Environ Health. 1993;39(2):139-47.

17. Iwado H, Koyano M, Goto S, Kira S, Hayatsu H. Ubiquitous presence of mutagenic and antimutagenic components in air-borne particulates of two Japanese cities. Mutat Res. 1994;322(4):329-39.

18. Binkova B, Dobias L, Wolff T, Sram RJ. 32P-postlabeling analysis of DNA adducts in tissues of rats exposed to coke-oven emissions. Mutat Res. 1994; 307(1):355-63.

19. Husgafvel-Pursiainen K. Genotoxicity of environmental tobacco smoke: a review. Mutat Res. 2004;567(2-3):427-45.

20. Aoki Y, Sato H, Nishimura N, Takahashi S, Itoh K, Yamamoto M. Accelerated DNA adduct formation in the lung of the Nrf2 knockout mouse exposed to diesel exhaust. Toxicol Appl Pharmacol. 2001;173(3):154-60.

21. Nohmi T, Katoh M, Suzuki H, Matsui M, Yamada M, Watanabe M, Suzuki M, Horiya N, Ueda O, Shibuya T, et al. A new transgenic mouse mutagenesis test system using Spi- and 6-thioguanine selections. Environ Mol Mutagen. 1996;28(4):465-70.

22. Nohmi T, Masumura K. Molecular nature of intrachromosomal deletions and base substitutions induced by environmental mutagens. Environ Mol Mutagen. 2005:45(2-3):150-61.

23. Masumura K, Sakamoto Y, Kumita W, Honma M, Nishikawa A, Nohmi T. Genomic integration of lambda EG10 transgene in gpt delta transgenic rodents. Genes Environ. 2015;37:24.

24. Nohmi T, Masumura K, Toyoda-Hokaiwado N. Transgenic rat models for mutagenesis and carcinogenesis. Genes Environ. 2017;39:11.

25. Hashimoto AH, Amanuma K, Hiyoshi K, Sugawara Y, Goto S, Yanagisawa R, Takano H, Masumura K, Nohmi T, Aoki Y. Mutations in the lungs of gpt delta transgenic mice following inhalation of diesel exhaust. Environ Mol Mutagen. 2007;48(8):682-93.

26. Hashimoto AH, Matsumoto M, Masumura K, Nohmi T, Aoki Y. In vivo mutagenesis caused by diesel exhaust in the testis of gpt delta transgenic mice. Gene Environ. 2009;31(1):1-9.

27. Yagishita M, Kageyama S, Ohshima S, Matsumoto M, Aoki Y, Goto S, Nakajima D. Atmospheric concentration and carcinogenic risk of polycyclic aromatic hydrocarbons including benzo[c]fluorene, cyclopenta[c,d]pyrene, and benzo[j]fluoranthene in Japan. Atmos Environ. 2015;115:263-8.

28. Mineki S, Kawakami Y, Nakajima D, Shiozaki T, Sugita K, Shiraishi F, Takagi Y, Goto S. Recovery rate in the concentration of semivolatile polycyclic aromatic hydrocarbon(PAH) solutions. J Environ Chem. 2008;18(1):43-50.

29. Inoue K, Takano H, Ichinose T, Tomura S, Yanagisawa R, Sakurai M, Sumi D, Cho AK, Hiyoshi K, Kumagai Y. Effects of naphthoquinone on airway responsiveness in the presence or absence of antigen in mice. Arch Toxicol. 2007:81(8):575-81.

30. Ichinose T, Furuyama A, Sagai M. Biological effects of diesel exhaust particles (DEP). II. Acute toxicity of DEP introduced into lung by intratracheal instillation. Toxicology. 1995;99(3):153-67.

31. Nohmi T, Suzuki T, Masumura K. Recent advances in the protocols of transgenic mouse mutation assays. Mutat Res. 2000;455(1-2):191-215.

32. Hashimoto AH, Amanuma K, Hiyoshi K, Takano H, Masumura K, Nohmi T, Aoki Y. In vivo mutagenesis induced by benzo[a]pyrene instilled into the lung of gpt delta transgenic mice. Environ Mol Mutagen. 2005;45(4):365-73.

33. Hashimoto AH, Amanuma K, Hiyoshi K, Takano H, Masumura K, Nohmi T, Aoki $Y$. In vivo mutagenesis in the lungs of gpt-delta transgenic mice treated intratracheally with 1,6-dinitropyrene. Environ Mol Mutagen. 2006;47(4):277-83.
34. Takano H, Yanagisawa R, Ichinose T, Sadakane K, Yoshino S, Yoshikawa T, Morita M. Diesel exhaust particles enhance lung injury related to bacterial endotoxin through expression of proinflammatory cytokines, chemokines, and intercellular adhesion molecule-1. Am J Respir Crit Care Med. 2002;165(9):1329-35.

35. Sanbongi C, Takano H, Osakabe N, Sasa N, Natsume M, Yanagisawa R, Inoue K, Kato Y, Osawa T, Yoshikawa T. Rosmarinic acid inhibits lung injury induced by diesel exhaust particles. Free Radic Biol Med. 2003;34(8):1060-9.

36. Nakabeppu Y, Sakumi K, Sakamoto K, Tsuchimoto D, Tsuzuki T, Nakatsu Y. Mutagenesis and carcinogenesis caused by the oxidation of nucleic acids. Biol Chem. 2006:387(4):373-9.

37. Lee DH, Pfeifer GP. Translesion synthesis of 7,8-dihydro-8-oxo-2'-deoxyguanosine by DNA polymerase eta in vivo. Mutat Res. 2008;641(1-2):19-26.

38. Sun Y, Taguchi K, Sumi D, Yamano S, Kumagai Y. Inhibition of endothelial nitric oxide synthase activity and suppression of endothelium-dependent vasorelaxation by 1,2-naphthoquinone, a component of diesel exhaust particles. Arch Toxicol. 2006;80(5):280-5.

39. Masumura K, Matsui K, Yamada M, Horiguchi M, Ishida K, Watanabe M, Wakabayashi K, Nohmi T. Characterization of mutations induced by 2-amino-1-methyl-6-phenylimidazo[4,5-b]pyridine in the colon of gpt delta transgenic mouse: novel G:C deletions beside runs of identical bases. Carcinogenesis. 2000;21(11):2049-56.

40. Swiger RR, Cosentino L, Masumura KI, Nohmi T, Heddle JA. Further characterization and validation of gpt delta transgenic mice for quantifying somatic mutations in vivo. Environ Mol Mutagen. 2001:37(4):297-303.

41. Endo O, Goto S, Nakajima D, Matsushita H. Mutagenic activity of airborne particles in Center of Metropolitan Tokyo over the past 20 years. J Environ Chem. 2016;26(1):1-7.

42. Diesel vehicle control. http://www.kankyo.metro.tokyo.jp/en/automobile/ diesel.html. Accessed 12 Nov 2018.

43. Aoki Y. Evaluation of in vivo mutagenesis for assessing the health risk of air pollutants. Genes Environ. 2017;39:16.

44. Carcinogenic potency database. https://toxnet.nlm.nih.gov/cpdb/. Accessed 12 Nov 2018.

45. Hsieh P, Yamane K. DNA mismatch repair: molecular mechanism, cancer, and ageing. Mech Ageing Dev. 2008;129(7):391-407.

46. Honjo T, Kinoshita K, Muramatsu M. Molecular mechanism of class switch recombination: linkage with somatic hypermutation. Annu Rev Immunol. 2002;20(1):165-96

47. Aoki Y, Hashimoto AH, Sugawara Y, Hiyoshi-Arai K, Goto S, Masumura K, Nohmi T. Alterations in the mutagenicity and mutation spectrum induced by benzo[a]pyrene instilled in the lungs of gpt delta mice of various ages. Genes Environ. 2015;37:7.

48. Kasai $\mathrm{H}$. What causes human cancer? Approaches from the chemistry of DNA damage. Genes Environ. 2016;38:19.

\section{Ready to submit your research? Choose BMC and benefit from:}

- fast, convenient online submission

- thorough peer review by experienced researchers in your field

- rapid publication on acceptance

- support for research data, including large and complex data types

- gold Open Access which fosters wider collaboration and increased citations

- maximum visibility for your research: over $100 \mathrm{M}$ website views per year

At BMC, research is always in progress.

Learn more biomedcentral.com/submissions 